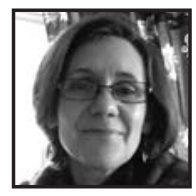

\title{
The Novice With Expertise: Is There a Leadership Role for Preservice Teachers in Times of Educational Change?
}

\author{
Avril Aitken, Bishop's University
}

\section{ABSTRACT}

Teachers working in secondary schools in Quebec are in the initial stages of the implementation of a new curriculum. In contrast, preservice teachers completing their studies are prepared to use the programs and approaches. This article explores the notion of teacher leadership for the "novice with expertise." Competing conceptions of teacher leadership are presented, followed by an examination of preservice teachers' representations of teacher leadership and tentative suggestions regarding the possibilities of leadership for preservice teachers.

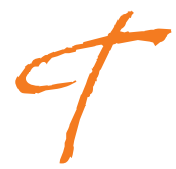

he challenges of educational reforms that have been observed in different contexts throughout North America are currently the lived reality of educators in the province of Quebec. These challenges, as Earl and Katz (2000) write, include difficulties provoked by directives that are evolving or contradictory, the unending series of complex initiatives, and policy and program documents that provide limited guidance regarding the designated key concepts. These difficulties are compounded for educators in English language institutions in the province who may have to wait for translations of the original French language documents. Additionally, the new programs require teachers to develop and evaluate student competency, as has been the trend in French speaking countries in the European Union (Jonnaert \& M'Batika, 2004). The development of competency requires that teachers assist students to increase their knowledge and skill as well as autonomy so that they take successful action in a range of complex situations. Evaluation of 
competency focuses on the process and outcomes of the students' strategic use of their knowledge and skill in such situations (Lafortune, 2005). This is a significant contrast to reforms in other English speaking countries. While the implementation of competency-based programs is being studied and is documented in French language texts (Lafortune \& Deaudelin, 2001; Lafortune, 2004), there is little being written in English. Living through this period requires a high degree of tolerance for uncertainty; leading through this period remains a challenge, despite increasing knowledge of effective leadership (Leithwood, Louis, Anderson, \& Wahlstrom, 2004).

There is no shortage of angles from which to consider educational change and much has been written about the role of leadership. However, my personal interest is in teacher professional identity, so my concerns are connected to the role that teachers play in times such as these. What follows is an exploration of a question that has arisen for me as a result of my current role in education in the province. I am a professor in a School of Education at one of the few English language universities in Quebec. I am also, however, involved in a large-scale, longitudinal, participatory research project that has a preparation component targeting leadership in the implementation of the new policies and programs (Projet Accompagnement Recherche Formation).

My current work has added new insight to my understanding of our particular context of educational change. Before joining the university in 2006, I worked with teacher teams from the English language schools that were piloting the new secondary level programs as part of a Ministry research initiative. Additionally, I worked with the research team analyzing the reform-driven efforts of teachers from across the province. What I have observed in these different contexts has made me acutely aware of the gap between the extent to which preservice teachers at the university are building understanding of the new curriculum, and the degree to which it is being used in the secondary schools in the province.

Preservice teachers will head into placements where they may have more knowledge of their program documents than the teams they are joining. Many of the teachers in the schools may be in the initial phases of the implementation process and may be operating with little training to support program use. In contrast, by the time the preservice teachers leave the university for their final, fourth-year placement, they will have worked individually and collaboratively to develop multiple unit plans and they will have participated in repeated peer evaluation and feedback processes regarding their work, some of which they may have piloted in previous placements. These preservice teachers demonstrate significant confidence regarding 
their ability to implement competency-based programs and to understand the associated theoretical foundations.

Datnow (2000) writes that teachers "need to own the process of change" ( $p$. 131), yet for preservice teachers leaving current teacher preparation programs, "change" and its "ownership" may hold a completely different sense than it does for the more experienced teachers who will soon become colleagues. As new teachers, they may, as Hargreaves (2005) notes, "have no habits to abolish nor practices to abandon. The new curriculum [is] the curriculum they [have] been prepared to teach" (p. 973). This raises the question of what contribution preservice teachers and recent graduates may be able to make in their new schools in this demanding period.

There is the perception, described by Hargreaves (2005), that teachers who are new to the profession are "finding their feet" in the first few years of their careers; this perspective might be associated with the notion that they are not yet ready to take on a leadership role. Yet, while they may be considered novices, M. Turnbull's (2005) study demonstrates that preservice teachers can take effective professional action in their placements, and this is influenced by professional knowledge associated with, for example, curriculum documents and policies. While this supports the possibility of novices having pertinent expertise, B. Turnbull (2005) notes that they are unlikely to be asked their opinion and their suggestions are often viewed as less pertinent than those of their seasoned colleagues.

How, then, might they contribute in this period of educational change? Will they be able to take on leadership at an early stage in their careers? What factors will influence their ability to do so? How do they conceive of teacher leadership?

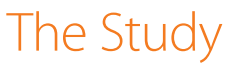

The final question was raised in a study with preservice secondary level teachers who are in the last year of their four-year program. The question was asked in the context of a course that requires the preservice teachers to plan collaboratively for interdisciplinary teaching and learning using the new programs. The tension between being a novice in the school setting yet having a certain degree of expertise with the documents had arisen several times. 
The students were given a form to complete on which they were asked, "What words or phrases come to mind when you think of teacher leadership?" In connection with that question, they were asked to reflect on the likelihood that they would one day be a teacher leader. To provoke self-assessment and stimulate their reflection, they were given a six-point numbered scale on which to indicate the possibility. The forms were collected for analysis. The discussion that followed was not recorded for structured analysis.

Seven of the 22 preservice teachers indicated a strong belief that they would be a teacher leader one day. Overall, 20 of the 22 students chose either the number 1 or 2 on the six-point scale and no one circled a number on the lower half. It would appear that most view teacher leadership as an expected dimension of their future careers. While it can be suggested that these preservice teachers are demonstrating what has been characterized as "the often admirable, frequently infectious but sometimes questionable enthusiasm of youth" (Hargreaves, 2005, p. 963), the assertions of these preservice teachers might also be related to the way they conceive of teacher leadership. It is Hargreaves' thought-pertaining to the concept of teacher leadership - that served as the prompt to carry out an exploratory reflection, the results of which are shared in this text. It begins with the following question:What leadership role might preservice or newly graduated teachers play in the context of educational change in the province of Quebec?

The question is complex and answers are shaped by individual and shared conceptions of teacher leadership. Thus, the notion of teachers as leaders is the starting point. It is followed with an examination of the representations made by the preservice teachers, which are organized under three headings that are associated with Donaldson's (2006) model of leadership as relational. The text concludes with tentative thoughts about the leadership role that preservice teachers may make in this period of educational change.

\section{Teacher Leadership}

Teacher leadership is commonly described as consisting of two fundamental types of roles: formal and informal (Muijs \& Harris, 2006). The formal roles are viewed as positions that are part of a hierarchical structure, positions that are associated with titles such as department head, mentor teacher, or instructional coach, to name a few. These positions, as Donaldson (2007) suggests, are associated with 
knowledge, authority, and power. Danielson (2007) writes that individuals who serve as formal teacher leaders "typically apply for their positions and are chosen through a selection process [and] receive preparation for their new responsibilities" (p. 16). Conversely, Johnson and Donaldson (2007) describe how appointments of teacher leaders may be made without a formal process, and thus, other teachers may view the selection as an act of favoritism. Lattimer (2007) describes this as a process of anointing teacher leaders, which can result in alienation for the one who has been selected.

In contrast to formal leaders, informal leaders are understood to "arise organically" (Lattimer, 2007, p. 71) or "emerge spontaneously" from among the teachers themselves (Danielson, 2007, p. 16). This emergence is viewed as a result of personal initiative and the ability to influence, "stem[ming] from the respect they command from their colleagues through their expertise and practice" (Danielson, 2007 , p. 16). While informal leaders may not need to be designated as such by a higher power, in some circumstances, their own right to authority may be called into question by their peers, for reasons of age or career stage, if either of these are associated with inexperience (Johnson \& Donaldson, 2007).

The above exploration of formal and informal teacher leaders demonstrates that the discussion is often shaped by the perspective of leadership as an entitlement combining "superior judgment and knowledge with superior authority and power" (Donaldson, 2007, p. 26). There are alternate views of teacher leadership that contrast with the hierarchical model. Muijs and Harris (2006) write of a form where"the nature and purpose of leadership is the ability of those within a school to work together, constructing meaning and knowledge collectively and collaboratively" (p. 962). Bennett, Harvey, Wise, and Woods (2003) echo the notion of teachers participating in what they describe as distributed leadership. In a review of the literature, they draw out the characteristics of such leadership. It is, they write, "an emergent property of a group or network of interacting individuals" (p. 7), through which the "boundaries of leadership" are opened so that "varieties of expertise are distributed across the many, not the few" (p. 7). Further to this, Donaldson's (2007) relational model of leadership conceives of "leadership as residing not in individuals, but in the spaces among individuals" (p. 26). Muijs and Harris (2006) write that there are three implications of this type of alternative to the hierarchical model:

Firstly, it implies a different power relationship within the school where the distinctions between followers and leaders tend to blur. Secondly, it has implications for the division of labour within a school, particularly when the tasks facing the organisation are shared more widely. Thirdly, it opens up the 
possibility of all teachers becoming leaders at various times. It is this last dimension that has the most potency and potential for school improvement because it is premised upon collaborative forms of working among teachers. (p. 962)

Crowther, Kaagan, Ferguson, and Hann's (2002) Teacher as Leader Framework proposes 24 types of actions considered to be forms of leadership. The actions are presented under six headings: Teacher leaders

[c]onvey convictions about a better world....[s]trive for authenticity in their teaching, learning, and assessment practices....[f]acilitate communities of learning through organization-wide processes....[c]onfront barriers in the school's culture and structures....[t]ranslate ideas into sustainable systems of action....[and] [n]urture a culture of success. (p. 4-5)

It is understood that through collective action, all will contribute to meeting the "complex needs of school communities in a rapidly changing world" (p.6).

Along similar lines, Donaldson's (2007) model proposes that three facets of daily school life provide contexts for the exercise of relational leadership: "as educators attend to the quality of relationships, insist on commitment to school's purpose and goals, and examine and improve instruction" (p. 26). Significantly, attention to these three dimensions - people, purpose, and practice-is a direct target of the preservice programs for teachers in Quebec (Ministère de l'Éducation, 2001). The recently implemented provincial approach to teacher preparation is competency-based and its rationale is described as follows,

Since the role of the teacher and the context of teaching have changed, new resources (knowledge, skills, attitudes) are required to practice the profession. Certification in a given subject is no longer the sole qualification needed....teachers must acquire the more complex competencies that underlie the new professionality (Ministère de l'Éducation, 2001, p. 23).

The three dimensions of school life connected to leadership: people, purpose, and practice, about which Donaldson (2006) writes can be identified within the Quebec teacher competencies which are the targets for preservice teacher learning (Ministère de l'Éducation, 2001). For example, cooperation, collaboration, and consensus building are program features. A preservice teacher, upon completion of the program, should be able, among other things, to: "contribute to the work of the teaching 
team in an effective manner; provide constructive criticism and make innovative suggestions" (p. 141). The preservice teacher should be able to "adjust his or her actions to the educational objectives of the school and contribute to the attainment of these objectives by becoming personally involved in school projects" (p. 139). Additionally, the teacher competencies include the ability to "engage in professional development individually and with others" (p. 143), so that upon completion of the program, the graduate can "engage in rigorous reflexive analysis on specific aspects of his or her teaching" (p. 143). It might be surmised that preparation for participating in a school through relational leadership is a target of preservice preparation in the province of Quebec.

\section{Teacher Leadership? The Preservice Teacher Perspective}

In order to explore the possibilities that relational leadership presents for preservice teachers, their perceptions of teacher leadership are presented below using Donaldson's (2006) three dimensions, people, purpose, and practice, as a means to organize the ideas.

Donaldson (2007) refers to the role of the first dimension, People, and the significance of "attend[ing] to the quality of relationships" (p. 27). The notion of quality relationships as an important element of teacher leadership was clear in the preservice teachers' representations. This extended to relationships with the principal, with peers, and with students. The skills the preservice teachers named included those that lead to positive interactions, for example, cooperation, understanding of others, enthusiasm, effective listening, helpfulness, and openness. Also evident were skills associated with creating relationships among others:"creates a positive dynamic within a teaching team and pushes for the best in everyone," "able to recognize the various strengths of coworkers and try to draw out those strengths," and "brings others into the group that are excluded." The people dimension also extended beyond building teams, into influencing change. The teacher leader, they wrote, "can defuse problem situations," "give feedback," and provide "constructive criticism." These are the relational skills that, as Donaldson (2007) suggests, pull people together to work on initiatives, rather than pushing them to collaborate.

Donaldson's (2007) second dimension, Purpose, refers to "insist[ence] on commitment to school's purpose and goals" (p. 27). The preservice teachers identified purpose and commitment as being essential to teacher leadership. The notion of purpose can be identified in the notion of "a desire" to "work toward improvement" and to "seek opportunities to make positive changes." Their comments extended further, 
into looking for ways to "bring in new ideas," but also through "giving opinions on the education system for future improvements." As one individual wrote, the teacher leader "does not just accept something he or she does not agree with." This dimension would include their referral to "promoting a cause" which underlines that the changes and improvements are not simply viewed to be in one's classroom.

Donaldson's (2007) third dimension, Practice, refers to action to "examine and improve instruction" (p. 27). The notion of Practice can be connected to the preservice teachers' suggestions that the teacher leader "takes risk in order to learn," "implements and experiences new techniques, skills, and activities," which it can be suggested, leads to "evolving teacher skills," which are in turn connected to being "reflective."

Donaldson (2007) calls the three dimensions "assets" that teachers contribute to "the school leadership mix" (p. 27). He underlines that the assets are interdependent. This was reflected by many of the preservice teachers both in their descriptions of teacher leaders and the statements they made about their own potential as a teacher leader. "I think of a teacher who takes the initiative to promote a cause and has the people skills to have others follow. Such teachers have influence and others validate their opinion." Another wrote, "Teacher leadership means giving opinions about the education system for future improvements, also working in a team with others to gain new knowledge and advice." A third expressed the three dimensions in light of personal aspirations,

I want to create the best environment for my students and in order to do this, being able to try new approaches and research data on learning will be crucial to accomplishing this. I not only enjoy communicating/debating with others in order to learn, but also to push for the best approaches.

Still another described the teacher leader as,

a teacher who is not afraid to try new things, a teacher who shares his or her experiences, good or bad, not just when approached about them, a teacher who does not just accept something that he or she does not agree with, a teacher who seeks opportunities to make positive changes ... I feel that is a part of my commitment to teaching to do all that I can to improve the education system. I could never see myself passively accepting something that I think could be improved upon. 
Significantly, only two of the students used the language of formal leadership when describing what came to mind when they thought of teacher leaders. Additionally, there was only one reference to a selection process that would "put" a teacher "into a situation where he or she is expected to take charge." On the other hand, the word "initiative" and similar representations appeared over and over, in phrases such as, "taking the lead," "take on a role," and "takes charge."

The above presentation of the preservice teachers' perceptions of teacher leaders demonstrates that they overwhelmingly used terms that can be associated with two very specific educational discourses: leadership as shared (rather than hierarchical) and teacher leader as collaborator (rather than expert). The educational discourses that are taken up by a teacher are one of the three factors that-interdependently-shape the professional identity. The second contributing factor is the teacher's desire, the deeply held, conscious or unconscious hopes. Discourse and desire intersect as the teacher enters into a new interaction with another; the resulting relationship is the third contributing factor. The way in which power is distributed in the interaction will influence the way the teacher acts on what he or she knows, believes, values, and desires. The lived experiences of working through these moments of interaction between teacher and student(s), teacher and principal, teacher and colleague(s), and so on, shape the continuous and fluid process of the formation of teacher identity (Hollway, 1989; Aitken, 2005). With respect to the preservice teachers involved in this study, their discursive representations of teacher leadership as collaborative and their self-representations as future teacher leaders suggest that leadership will, at some point, be part of their professional identity given the right relational context, that is, where a supportive and collaborative culture exists. As the studies of Grant (2006) and Muijs and Harris (2006) underscore, trust and supportive relationships must exist for teacher leadership to flourish. While this paints a hopeful picture for the future, it does not necessarily describe the possibilities of leadership for current preservice teachers and those newest to the profession at this moment in time.

\section{Possibilities of Leadership for Preservice Teachers}

If the relational or distributed model of leadership is the predominant approach in the school, there would be opportunities for the preservice teachers to draw on many of the competencies they have been developing: collaborative planning, engaging in feedback processes with peers, and participating in collective decision making. Such a model would also make effective use of the preservice teacher's knowledge of the new curriculum. On the other hand, if a hierarchical model were the 
commonly held approach to leadership in the school, it would likely preclude preservice teachers from taking up a teacher leader role. Their knowledge of the curriculum may be viewed as pertinent; however, as mentioned earlier, they may be perceived first as novices who "lack the tools of classroom management," are naïve about change, and "without adult history or professional memory" (Hargreaves, 2005, p. 972).

If one looks within the larger context of the school in which the preservice teacher is placed, it is possible to find a more intimate context, that is, the collaboration between the preservice teacher and the associate teacher. Following Donaldson's (2007) notion of "leadership as residing not in individuals, but in the spaces among individuals" (p. 26), the preservice and associate teacher collaboration can be viewed as space for many fruitful opportunities for pooling expertise and working jointly toward the shared goal of student success. It is also possible that in this context the preservice teachers' knowledge of how to work with the program materials and their experience in planning collaboratively will lead to effective teaching, and that these successes will, in turn, be viewed as winning models by their experienced colleagues. As Guskey (2002) notes, it is through witnessing successful action associated with program changes, that teachers are convinced to adhere to such changes.

Additionally, the preservice teachers may influence others if they effectively model one of the ten roles for teacher leaders that are proposed by Harrison and Killion (2007), the "Learner." This role is considered to be among the most important. It is different from the authors' other suggestions, which are contingent on a hierarchical model demanding expert knowledge. The role of Learner stands out because it attributes teacher leadership to modeling the application of analysis and reflection on personal practice, which is not necessarily contingent upon years of teaching experience. Thus, the role of Learner may be a promising teacher leader role for preservice teachers, particularly as reflective practice is a target of teacher preparation in the province of Quebec (Ministère de l'Éducation, 2001). Given the range of potential spaces for leadership described above, it is entirely possible that the preservice teachers will play a significant and positive leadership role while in their placements and beyond. 


\section{Some Thoughts on the Broader Context}

The initial question that prompted this reflection-how might preservice or novice teachers contribute in this context of change-is directly connected to my own practice as a teacher educator in the province of Quebec and to my concern for the preservice teachers who will enter into schools where teams may be struggling with program changes. It might rightfully be said that this text provides only limited insight into a narrow context of change. At the same time, it can be asserted that the waves that are being felt in Quebec are ripples of two much greater areas of concern being examined internationally: the possible purposes of teacher education programs and the impact of a changing world on teacher practice. The government of Quebec-whose educational reforms have extended to the restructuring of the teacher education programs - is not alone in taking on the question of how to better conceive of a system of education and determine how to prepare its teachers. The Association of Canadian Deans of Education (2006) recently approved the "Accord on Initial Teacher Education." One intention of this accord is to provide principles for the preparation of preservice teachers. The text begins with the context, referred to as, "today's changing world." The same words are found in the title of the DarlingHammond and Bransford (2005) publication in which the authors examine the question of what should now be expected of teachers and what that means to teacher educators in the Unites States. Similarly, the Australian context is described in the Butcher and McDonald (2007) text, Making a Difference: Challenges for Teachers, Teaching and Teacher Education.

Preparing teachers to be leaders is not necessarily explicitly addressed in the above-mentioned texts. However, the two discursive positions that emerged in the small study described herein, that is, leadership as shared and teacher leader as collaborator, are echoed through a range of perspectives that advocate the importance of collaborative communities and the significance of teachers as learners. The lines between leading, collaborating, and learning are blurred in these texts, where attention is on preparation of effective teachers in-and for-a rapidly changing world. This raises the issue of which entry point is most pertinent when one wants to prepare preservice and new teachers to influence others in their schools. Is it through the explicit lens of leadership (Neumann, Jones, \& Webb, 2007; Turnbull, 2005)? Is it through the lens of collaboration? Or it is through the lens of lifelong learning? These are questions that merit the attention of teacher educators. They are certainly questions that will fuel my future reflection and action. 


\section{References}

Aitken, A. (2005). Fragile fixings: An exploration of the self-representations of white women teachers in one isolated northern Indigenous community. Doctoral dissertation, University of Ottawa.

Association of Canadian Deans of Education. (2006, October). Accord on Initial Teacher Education. Retrieved March 25, 2008, from the Canadian Society for the Study of Education Web site: http://www.csse.ca/ ACDE/TeacherAccord.pdf

Bennett, N., Harvey, J. A., Wise, C., \& Woods, P. A. (2003). Distributed leadership. Retrieved April 2, 2008, from the National College for School Leadership Web site: http://www. ncsl.org.uk/media/7B5/67/distributedleadership-literature-review.pdf

Butcher, J., \& McDonald, L. (Eds.). (2007). Making a difference: Challenges for teachers, teaching and teacher education. Rotterdam, The Netherlands: Sense Publishers.

Crowther, F., Kaagan, S. S., Ferguson, M. \& Hann, L. (2002). Developing teacher leaders: How teacher leadership enhances school success. Thousand Oakes, CA: Sage.

Danielson, C. (2007). The many faces of leadership. Educational Leadership, 65(1), 14-19.

Darling-Hammond, L., \& Bransford, J. (Eds.). (2005). Preparing teachers for a changing world: What teachers should learn and be able to do. San Francisco: Jossey-Bass.

Datnow, A. (2000). Gender politics in school reform. In N. Bascia \& A. Hargreaves, (Eds.), The sharp edge of educational change: Teaching, leading and the realities of reform (pp. 131-155). New York: Routledge Falmer.

Donaldson, G. (2006). Cultivating teacher leadership in schools: Connecting people, purpose and practice ( $2^{\text {nd }}$ ed.). New York: Teachers College Press.

Donaldson Jr., G. A. (2007). What do teachers bring to leadership? Educational Leadership, 65(1), 26-29.

Earl, L. \& Katz, S. (2000). Changing classroom assessment: Teachers' struggles. In N. Bascia \& A. Hargreaves, (Eds.). The sharp edge of educational change: Teaching, lead- ing and the realities of reform (pp. 97-111). New York: Routledge Falmer.

Grant, C. (2006). Emerging voices on teacher leadership: Some South African views [Electronic version]. Educational Management Administration Leadership, 34(4), 511-532.

Guskey, T. R. (2002). Professional development and teacher change [Electronic version]. Teachers and Teaching 8(3/4), 381-391.

Hargreaves, A. (2005). Educational change takes ages: Life, career and generational factors in teachers' emotional responses to educational change [Electronic version]. Teaching and Teacher Education, 21, 967-983.

Harrison, C. \& Killion, J. (2007). Ten roles for teacher leaders. Educational Leadership, 65(1), 74-77.

Hollway, W. (1989). Subjectivity and method in psychology: Gender, meaning and science. London, UK: Sage Publications.

Johnson, S. M. and Donaldson, M. L. (2007). Overcoming the obstacles to leadership. Educational Leadership, 65(1), 8-13.

Jonnaert, P. \& M'Batika, A. (2004). Les réformes curriculaires: Regards croisés, Québec: QC: Presses de l'Université du Québec.

Lafortune, L. (2004). Travailler en équipe-cycle: Entre collègues d'une école, Québec: QC: Presses de l'Université du Québec.

Lafortune, L. (2005). Compétences: Sens, développement, évaluation, accompagnement. Unpublished manuscript, MELS Université du Québec à Trois-Rivières, Trois-Rivières.

Lafortune, L. \& Deaudelin, C. (2001). Accompagnement socioconstructiviste. Pour s'approprier une réforme en éducation, Québec: QC: Presses de I'Université du Québec.

Lattimer, H. (2007). To help and not hinder. Educational Leadership, 65(1), 70-73.

Leithwood, K., Louis, K. S., Anderson, S. \& Wahlstrom, K. (2004). How leadership influences student learning. Learning from Leadership project. Retrieved November 27, 2007, from: www.wallacefoundation. 
org/NR/rdonlyres/E3BCCFA5-A88B-45D38E27-B973732283C9/0/ReviewofResearch LearningFromLeadership.pdf

Ministère de l'Éducation (2004). Quebec Education Program, Secondary school education, Cycle One, Québec, Gouvernement du Québec.

Ministère de l'Éducation, du Loisir et du Sport (2007). Quebec Education Program: Secondary school education, Cycle Two, Québec, Gouvernement du Québec.

Ministère de l'Éducation (2001). Teacher training: Orientations; professional competencies, Québec, Gouvernement du Québec.

Muijs, D. \& Harris, A. (2006). Teacher led school improvement: Teacher leadership in the UK [Electronic version]. Teaching and Teacher Education, 22, 961-972.

Neumann, M. D., Jones, L. C., \& Webb, P.T. (2007). Developing teachers' leadership knowledge: Pillars for the "New Reform" [Electronic version]. Teaching Education 18(3), 233-244.
Projet Accompagnement Recherche Formation (n.d.). Accompagnement Recherche Formation: Pour la mise en oeuvre du Programme de formation de l'école québécoise. Retrieved October 30, 2007, from www.uqtr.ca/accompagnementrecherche

Turnbull, B. (2005). Facilitating early career leadership through preservice training [Electronic version]. Teachers and Teaching, 11(5), 457-464.

Turnbull, M. (2005). Student teacher professional agency in the practicum [Electronic version]. Asia-Pacific Journal of Teacher Education, 33(2), 195-208.

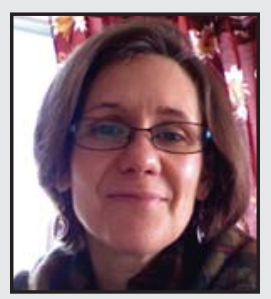

Avril Aitken, Ph.D. is an Assistant Professor in the School of Education at Bishop's University, Sherbrooke, Quebec. An educator for almost three decades, she has worked with teachers and teacher leaders across the province. Her current research interests include the construction of teacher professional identity. 